\title{
Correction to: Genome-wide SNP discovery for development of high-density genetic map and QTL mapping of ascochyta blight resistance in chickpea (Cicer arietinum $\mathrm{L}$.)
}

\author{
Amit Deokar ${ }^{1} \cdot$ Mandeep Sagi $^{1} \cdot$ Bunyamin Tar'an ${ }^{1}$ (I)
}

Published online: 27 April 2019

๑) Springer-Verlag GmbH Germany, part of Springer Nature 2019

\section{Correction to: Theoretical and Applied Genetics https://doi.org/10.1007/s00122-019-03322-3}

Unfortunately there was an error in the name of the gene "Ca-AKL18" in the discussion section. The correct name should read "CaAHL18".

The complete corrected sentence is given below:

A candidate gene CaAHL18 (AT-HOOK MOTIF CONTAINING NUCLEAR LOCALIZED 18) gene was identified within this region (Kumar et al. 2018). The CaAHL18 showed structural variation in the promoter region and had higher expression under ascochyta blight infection in the moderately resistant parent FLIP84-92C, suggesting that this gene is the most probable candidate involved in resistance to ascochyta blight in chickpea (Kumar et al. 2018).

The original article was corrected.

Publisher's Note Springer Nature remains neutral with regard to jurisdictional claims in published maps and institutional affiliations.

The original article can be found online at https://doi.org/10.1007/ s00122-019-03322-3.

\footnotetext{
Bunyamin Tar'an

bunyamin.taran@usask.ca

1 Department of Plant Sciences, College of Agriculture and Bioresources, University of Saskatchewan, Saskatoon, Canada
} 